\title{
Counteracting Hoax in Social Media Through Tabayyun By Islamic Student Community
}

Received:29-10-2021 ; Revised:24-12-2021 ; Accepted: 24-12-2021

\section{Iredho Fani Reza*)}

Universitas Islam Negeri Raden Fatah Palembang

E-mail: iredhofanireza_uin@ radenfatah.ac.id

*) Corresponding Author

\begin{abstract}
This study aims to find out hoaxes on social media and how the form of tabayyun and its implementation can be a method of preventing hoaxes spread on social media. Using this type of research mixed methods with the design of the Sequential Exploratory Strategy. The subjects in this study $\mathrm{N}$ Total $=514$ who were Muslim students at universities in Palembang City which were determined using purposive sampling technique. The data collection method used an online survey. Data analysis using coding techniques (open coding, axial coding and selective coding) version 9 of the Atlas.ti program and product moment analysis and testing for level categorization of the IBM SPSS version 24 program. This study found, first, the form of hoaxes on social media: 1) News lie; 2) False information; 3) Does not match the facts. Second, students have not implemented tabayyun optimally in responding to news on social media. The form of the application of tabayyun is to seek the truth by thinking critically, observing and confirming the news and information obtained.
\end{abstract}

\begin{abstract}
Abstrak: Penelitian ini bertujuan untuk mengetahui hoax di media sosial dan bagaimana bentuk tabayyun dan implementasinya dapat menjadi metode pencegahan penyebaran hoax di media sosial. Menggunakan jenis penelitian metode campuran dengan desain Strategi Eksplorasi Sequential. Subyek dalam penelitian ini $N$ Total $=514$ yang merupakan mahasiswa muslim pada perguruan tinggi di Kota Palembang yang ditentukan dengan teknik purposive sampling. Metode pengumpulan data menggunakan survei online. Analisis data menggunakan teknik pengkodean (open coding, axial coding dan selective coding) versi 9 program Atlas.ti serta analisis dan pengujian product moment untuk kategorisasi level program IBM SPSS versi 24. Penelitian ini menemukan, pertama, bentuk hoax di media sosial: 1) Berita bohong; 2) informasi palsu; 3) Tidak sesuai dengan fakta. Kedua, siswa belum menerapkan tabayyun secara maksimal dalam menanggapi berita di media sosial. Bentuk penerapan tabayyun adalah
\end{abstract}


mencari kebenaran dengan cara berpikir kritis, mengamati dan membenarkan berita dan informasi yang diperoleh.

\section{INTRODUCTION}

T The modern era is full of advances in science and technology. It has a real impact on every aspect of human life. In fact, according to researchers, Indonesia is not only carrying out the industrial revolution 4.0 era (Rojko, 2017), but it has started to touch the realm of Society 5.0 (Sugiono, 2020). Evidence for society 5.0 can also be seen from almost every aspect of human life through online processes.

One aspect of life is education at the university level. This also has an impact on students who are a productive young group who tend to be the highest internet users in the world, even students in Indonesia are one of the highest users of technology, internet and social media in the world.

Digitalisasi memberikan pengaruh besar pada pendidikan dan kehidupan sosial. In education, learning media has shifted from conventional to digital (Amra, 2016). As research conducted by Cambridge International shows that Indonesian students are one of the highest users of educational technology in the world (Cambridge Assessment International Education, 2018).

Students are not only the foundation for future environmental protection but also the seeds of citizens (Fei Tong and Chiajung Lin, 2010). One of the surveys conducted by Cambridge Assessment International Education (2018) found that Indonesian students use technology in the classroom more than many other countries, often outperforming more developed countries. Indonesian students are the highest globally in the use of IT suites or computer rooms $(40 \%)$. They are also the second highest in the world for using a desktop computer (54\%), only behind the United States.

More than two thirds of Indonesian students $(67 \%)$ use smartphones in class, and even more use them to do homework (81\%). However, more traditional tools such as pen and paper are still used frequently by students in the classroom and at home, and whiteboards are still popular in Indonesian classrooms with $90 \%$ of teachers saying they use them. Indonesian students are also almost tied to the United States for the highest use of laptops for doing their homework $(84 \%$, compared to $85 \%$ in the United States) (Cambridge Assessment International Education, 2018).

In this paper, I highlight the use of social media among students. Many forms of social media are used by students such as Facebook, Instagram, Twitter and other social media platforms. Information from social media also varies. Starting from education information, government. However, information on social media itself is a new polemic in human life. Where the question arises, can the information on social media be accounted for? Because of the many hoax news circulating on social media. According to Prasetijo (2017) hoaxes are false, outdated or unverifiable information that is spread spontaneously by Internet users.

In the perspective of Islamic psychology, I am interested in revealing whether this hoax on social media can be overcome? In QS. al-Hujurat [49] : 6 said: "O you who believe! If someone who is wicked comes to you with news, then examine the truth, so that you do not harm a people because of ignorance (recklessness), which in the end you will regret what you did. It can be seen that Allah Almighty ordered humans to clarify first when they get news that is not yet known to be true which is indicated to be a hoax.

This study aims to provide a method of overcoming hoax news through the Tabayyun method in the perspective of Islamic psychology based on QS. Al-Hujurat [49] : 6. According to Fathoni et al (2019) "the behavior of checking, criticizing, and 
clarifying untrue information and not in a hurry to spread information". In the perspective of Islamic Psychology, Allah SWT ordered to check and re-examine and in Islam it is called tabayyun.

In the fatwa of the Indonesian Ulema Council No. 24 of 2017 explains that anyone who obtains content/information through social media (both positive and negative) may not immediately distribute it before it is verified and the tabayyun process is carried out and its usefulness is ensured. Furthermore, the Indonesian Ulema Council provides a method of tabayyun process for content/information that can be done with the following steps: 1) Ensure the aspect of the source of information (sanad), which includes personality, reputation, feasibility and trustworthiness; 2) Ensure the correctness of the content (matan), which includes the content and intent; 3) Ensure the context of the place and time as well as the background when the information is conveyed (Fatwa Majelis Ulama Indonesia Tentang Hukum Dan Pedoman Bermuamalah Melalui Media Sosial, 2017).

In the perspective of the Qur'an as a guide, humans have actually paid attention to hoaxes. Several words in the Qur'an such as ifk, kaẑaba, fitnah, khud'a, qaul al-zūr, buhtan, iftara, tahrif, garur has illustrated the context of the hoax (Setiyanto, 2019).

Based on the background of the problem above, I am interested in conducting a study to find out whether hoaxes on social media can be overcome through tabayyun. So the focus of the search in this study is to find out the typical hoaxes encountered by students and the application of existing tabayun methods to overcome these hoaxes.

So that there are two questions in this study: What are the typical hoaxes encountered by students? How is the application of the tabayun method to deal with hoaxes?.

\section{METHOD}

This research is a type of mixed methods research with a Sequential Exploratory Strategy design (Creswell, 2014). The subjects in this study were the Islamic student community at one of the Religious Universities at Indonesia. Determination of the subject in this study using purposive sampling technique (Seidman, 2006). The criteria in this study include: 1) Muslim students are active in religious universities in Indonesia; 2) Men and women; 3) Youth between 17-24 years old (World Health Organization, 2006); 4) Willing to be a research subject. The research subjects that were collected in this study were $\mathrm{N}=514$ who came from active students of UIN Raden Fatah Palembang.

The method of data collection in this research is to use the online survey method (primary method) and documentation method (secondary method). Online surveys collect data through the help of online media with the Google Form survey platform. In compiling online survey, this research used the Five Ws and an $\mathrm{H}$ technique (Singer, 2008) which reveals the social media phenomenon, the hoax phenomenon and the tabayyun phenomenon.

In addition, also use Fatwa Majelis Ulama Indonesia, how to do tabayyun on social media: 1) Ensure the aspect of the source of information (sanad), which includes personality, reputation, feasibility and trustworthiness; 2) Ensure the correctness of the content (matan), which includes the content and intent; 3) Ensure the context of the place and time as well as the background when the information is conveyed (Fatwa Majelis Ulama Indonesia Tentang Hukum Dan Pedoman Bermuamalah Melalui Media Sosial, 2017). While the documentation method in the form of books, journal articles and website pages that are authoritative and relevant to the theme of this research.

In the process of using a online survey this research. Has several stages before being used in the implementation of research. In the first stage, the initial draft of the online survey was prepared; The second stage, after the preparation, the review stage is carried out by two validators who have the capability of experts in Islamic Psychology and Social Psychology. These two expertises 
were chosen because the research themes with the themes of Tabayyun, social media and Hoax are very closely related to these two areas of expertise. The third stage, after being reviewed by the validator, the next stage is to revise it according to suggestions and directions from experts. The fourth stage is the preparation of an online survey using the google form platform. The fifth stage is the last stage, namely the process of using a research online survey for data collection.

In an effort to draw conclusions in this study. Divided into two types of data analysis methods. First, qualitative data analysis uses data analysis methods using coding techniques (open coding, axial coding and selective coding) (Creswell, 2012). In analyzing qualitative data, the researcher used the assistance of the Atlas.ti qualitative data analysis program version 9 (2021). Both quantitative data analysis uses several data analyzes such as product moment technique analysis and level categorization test. In analyzing quantitative data, the researcher used the help of the IBM SPSS version 24 statistical analysis program. The use of quantitative data analysis to complement qualitative data analysis.

\section{RESULTS AND DISCUSSION RESULTS \\ Research Subject Demographic Data}

This study used $\mathrm{N}=514$ subjects who were divided into male $(\mathrm{N}=117 / 23 \%)$ and female $(\mathrm{N}=397 / 77 \%)$. The subjects in this study were divided into three age categorizations in the youth age classification starting from 10-24 years old (World Health Organization, 2006). Because the subject of this research is young people who are active students in higher education. Then the distribution and distribution of the age of the subjects in the study were categorized as: $16-18$ years $(\mathrm{N}=147 / 29 \%)$, $19-20$ years $(\mathrm{N}=285 / 55 \%)$ and 21 years $(\mathrm{N}$ $=82 / 16 \%$ ).

The subject in this study is not only a student but has other activities besides being a student at a university. From $\mathrm{N}$ Total = $514,171(33 \%)$ claimed to have other activities and 343 (67\%) claimed to have no other activities.

\section{Intensity of Social Media Use}

The intensity of the use of social media in this study was divided into 4 categorizations including: < 1 hour, 1-3 hours, 3-5 hours, > 5 hours. The distribution of the data is as follows:

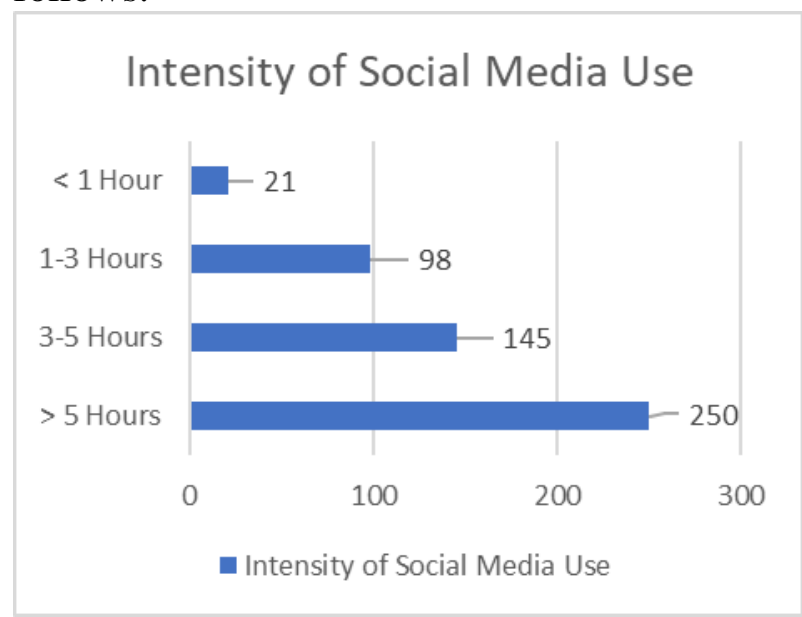

From the survey results, it was found that from the total number of research subjects $\mathrm{N}$ $=514$, the order of the intensity of the use of social media among students in this study was: 1) Time $>5$ hours $(\mathrm{N}=250 / 48 \%)$; 2$)$ Time 3-5 hours $(\mathrm{N}=145 / 28 \%)$; 3) Time 1-3 hours $(\mathrm{N}=98 / 19 \%) ; 4)$ Time $<1$ hour $(\mathrm{N}=$ $21 / 5 \%)$

In this study, I also carried out additional quantitative analysis in the form of product moment correlation analysis $(\mathrm{p}<0.05)$ to determine the relationship between the intensity of social media use and encounters with hoax news on social media. From the results of the analysis, it was found that there was a positive relationship between the intensity of social media use and encounters with hoaxes on social media (Sig value = $0.000)$. In the sense that students in the use of social media there is a tendency during the time of use that they will encounter hoax information.

\section{Correlations}

\begin{tabular}{c|c} 
Intensit & $\begin{array}{l}\text { Encount } \\
\text { y_Usag } \\
\text { er_With } \\
\text { e_Socia }\end{array}$ \\
1_Media & $\begin{array}{l}\text { Hows_- } \\
\text { Hoax_In } \\
\text { _Social_ } \\
\text { Media }\end{array}$ \\
\hline
\end{tabular}




\begin{tabular}{llr|r}
\hline $\begin{array}{l}\text { Intensity_Usage } \\
\text { _Social_Media }\end{array}$ & $\begin{array}{l}\text { Pearson } \\
\text { Correlation }\end{array}$ & & $.294^{* *}$ \\
\cline { 2 - 4 } & $\begin{array}{l}\text { Sig. (2- } \\
\text { tailed) }\end{array}$ & & \\
\cline { 2 - 4 } & $\mathrm{N}$ & 514 & 514 \\
\hline $\begin{array}{c}\text { Encounter_With } \\
\text { _News_Hoax_I }\end{array}$ & $\begin{array}{l}\text { Pearson } \\
\text { n_Social_Media }\end{array}$ & $.294^{* *}$ & 1 \\
& $\begin{array}{l}\text { Sig. (2- } \\
\text { tailed) }\end{array}$ & .000 & \\
\cline { 2 - 4 } & $\mathrm{N}$ & 514 & 514 \\
\hline
\end{tabular}

**. Correlation is significant at the 0.01 level (2tailed).

In addition, I conducted a statistical analysis of the comparison of the intensity of social media use with the tendency to encounter hoax news on social media on student subjects in this study $(\mathrm{N}$ Total $=$ 514). The result is that it doesn't take long to encounter hoaxes on social media, within less than 1 hour of access to social media, someone can already encounter hoax information.

Encounter_With_News_Hoax_In_Social_Media Tukey HSD ${ }^{\mathrm{a}, \bar{b}}$

\begin{tabular}{lr|r}
$\begin{array}{l}\text { Access Time Use } \\
\text { of Social Media }\end{array}$ & \multicolumn{1}{c|}{ N } & \multicolumn{1}{|c}{$\begin{array}{c}\text { Subset for alpha }=0.05 \\
1\end{array}$} \\
\hline 1 - 3 Hours & 98 & 23.4898 \\
\hline 3 - 5 Hours & 145 & 24.5103 \\
\hline$>$ 5 Hours & 250 & 24.6000 \\
\hline$<$ 1 Hour & 21 & 25.2381 \\
\hline Sig. & & .351 \\
\hline
\end{tabular}

Means for groups in homogeneous subsets are displayed.

a. Uses Harmonic Mean Sample Size = 58.207.

b. The group sizes are unequal. The harmonic mean of the group sizes is used. Type I error levels are not guaranteed.

\section{Age With Social Media}

In addition, I also conducted an analysis of the use of social media in terms of age on the student subjects in this study $(\mathrm{N}$ Total $=$ 514). The results show that the age range of 16-18 years is the age most often accessing social media.

\section{Intensity_Usage_Social_Media}

Tukey HSD ${ }^{\mathrm{a}, \mathrm{b}}$

\begin{tabular}{|c|c|c|}
\hline & & $\begin{array}{l}\text { Subset for alpha } \\
\quad=0.05\end{array}$ \\
\hline Age & $\mathrm{N}$ & 1 \\
\hline
\end{tabular}

\begin{tabular}{lr|r}
\hline $21>$ Years & 82 & 25.1220 \\
\hline $19-20$ Years & 285 & 25.1509 \\
\hline $16-18$ Years & 147 & 25.5646 \\
\hline Sig. & & .649 \\
\hline
\end{tabular}

Means for groups in homogeneous subsets are displayed.

a. Uses Harmonic Mean Sample Size = 133.294.

b. The group sizes are unequal. The harmonic mean of the group sizes is used. Type I error levels are not guaranteed.

\section{Forms of Hoax on Social Media}

What exactly is a hoax? In answering this, I conducted a survey of the subjects (N Total $=$ 514) in this study about their understanding of what a hoax is. From the survey results, three terms can be found that can define hoaxes on social media. The three terms regarding hoaxes on social media are as follows:

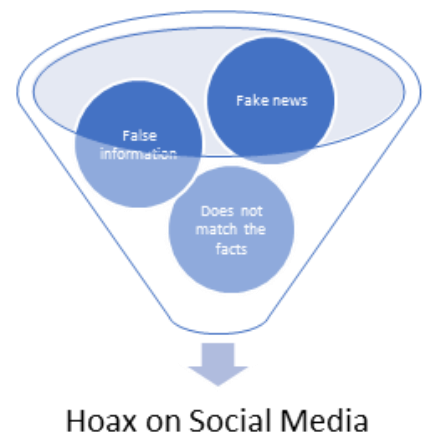

Based on the chart above, hoaxes on social media include three important components including: 1) Fake news; 2) False information; 3) Does not match the facts. So the definition of hoax on social media is false reporting or false information that does not match the facts on social media. Aspects of the hoax field on social media include: 1) The political field; 2) Health Sector; 3) Social Sector; 4) Religion sector; 5) Education sector; 6) Economic sector; 7) Cultural field. 


\section{Hoax Field in Social Media}

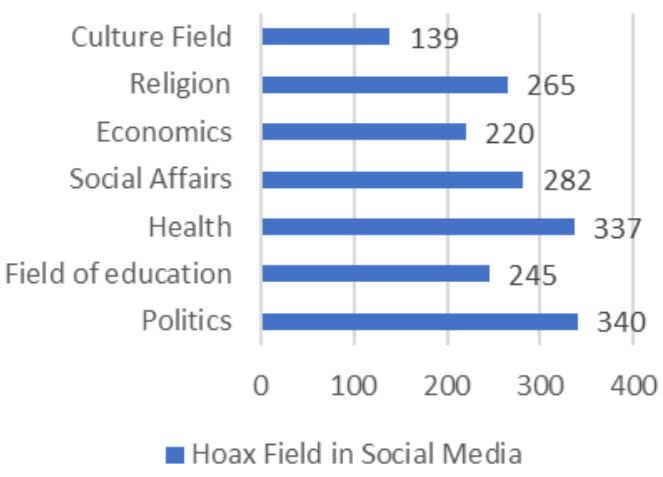

\section{Implementation of Tabayyun on Students in Preventing Hoaxes on Social Media}

According to the Indonesian Ulema Council, the tabayyun process method for content/information can be carried out with the following steps: 1) Confirmation of aspects of the source of information (sanad), which includes personality, reputation, feasibility and trustworthiness; 2) Ensure the correctness of the content (matan), which includes the content and intent; 3) Ensure the context of the place and time as well as the background when the information is conveyed (Fatwa Majelis Ulama Indonesia Tentang Hukum Dan Pedoman Bermuamalah Melalui Media Sosial, 2017).

I did an analysis with the help of a statistical program to find out how tabayuun is applied to students of the Muslim community. The following are the results of calculations using the SPSS version 24 program:

\begin{tabular}{|c|c|c|c|c|c|}
\hline No & $\begin{array}{c}\text { No } \\
\text { rm } \\
\text { S }\end{array}$ & $\begin{array}{c}\text { Sco } \\
\text { re }\end{array}$ & $\begin{array}{c}\text { Catego } \\
\text { ry }\end{array}$ & $\begin{array}{c}\text { Freque } \\
\text { ncy }\end{array}$ & $\begin{array}{c}\text { Percent } \\
\text { age }\end{array}$ \\
\hline 1 & $\begin{array}{c}X> \\
\mu+ \\
\sigma\end{array}$ & $\begin{array}{c}X> \\
11\end{array}$ & High & 114 & $23 \%$ \\
\hline 2 & $\begin{array}{c}\mu- \\
\sigma< \\
X \leq \\
\mu+ \\
\sigma\end{array}$ & $\begin{array}{l}8- \\
11\end{array}$ & $\begin{array}{l}\text { Mediu } \\
\mathrm{m}\end{array}$ & 255 & $49 \%$ \\
\hline 3 & $\begin{array}{c}X \leq \\
\mu- \\
\sigma\end{array}$ & $\begin{array}{l}X \\
\leq 7\end{array}$ & Low & 145 & $28 \%$ \\
\hline \multicolumn{4}{|c|}{ Grand Total } & $\mathrm{N}=514$ & $100 \%$ \\
\hline
\end{tabular}

Based on the results of the level categorization test above. The results obtained from the student subject $(\mathrm{N}$ Total $=$ 514). A total of $\mathrm{N}=114(23 \%)$ are in the high categorization, meaning that the group of students who tend to apply full tabayyun in responding to news on social media. A total of $\mathrm{N}=255(49 \%)$ are in the moderate categorization, meaning that the group of students who tend to apply tabayyun has not been completely, there is still a tendency to ignore tabayyun in responding to news on social media. While as many as $\mathrm{N}=145$ $(28 \%)$ are in the low categorization, meaning that the group of students who tend not to apply tabayyun in responding to news on social media. The following shows a graph of the comparison of values between each level of tabayyun categorization for Muslim community students:

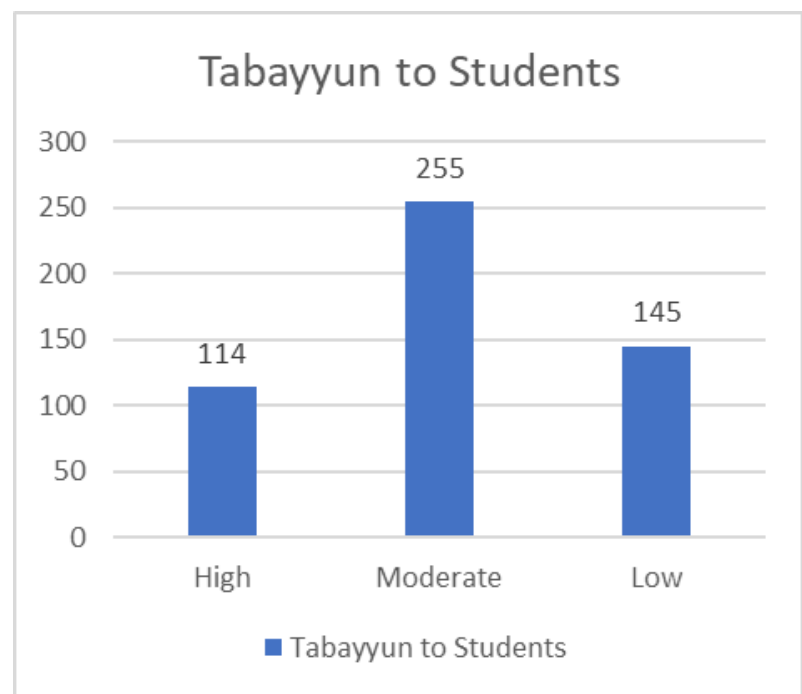

Implementation of tabayyun in terms of gender differences. Using the statistical program SPSS version 24. Based on comparative analysis using the comparison of the Mean value between men $(\mu=9.0855)$ and women $(\mu=8.9673)$. It was found that men were more likely to be persistent in receiving information on social media than women. 


\section{Report}

Tabayyun_In_Receiving_Information_In_Social_M edia

\begin{tabular}{ll|l|c} 
Gender & Mean & N & $\begin{array}{c}\text { Std. } \\
\text { Deviatio } \\
\mathrm{n}\end{array}$ \\
\hline Male & 9.0855 & 117 & 2.22669 \\
\hline Female & 8.9673 & 397 & 2.22507 \\
\hline Total & 8.9942 & 514 & 2.22382 \\
\hline
\end{tabular}

Furthermore, I also conducted an analysis of the comparison of the implementation of tabayyun in terms of age differences. Using the help of the SPSS statistical program version 24 . Based on a comparative analysis using Tukey's comparative analysis, those aged $21>$ years are more likely to apply tabayyun in receiving news and information on social media. Followed by 16-18 years old who apply tabayyun in receiving news and information on social media. Meanwhile, aged 19-20 years, there is a tendency that they are not optimal in applying tabayyun in receiving news and information on social media.

Tabayyun_In_Receiving_Information_In_Social_ Media

Tukey HSD ${ }^{\mathrm{a}, \mathrm{b}}$

\begin{tabular}{|c|c|c|}
\hline Age & $\mathrm{N}$ & $\begin{array}{c}\text { Subset for alpha }= \\
0.05 \\
1 \\
\end{array}$ \\
\hline $\begin{array}{l}19-20 \\
\text { Years }\end{array}$ & 285 & 8.9368 \\
\hline $\begin{array}{l}16-18 \\
\text { Years }\end{array}$ & 147 & 9.0340 \\
\hline $21>$ Years & 82 & 9.1220 \\
\hline Sig. & & .776 \\
\hline
\end{tabular}

Means for groups in homogeneous subsets are displayed.

a. Uses Harmonic Mean Sample Size $=133.294$.

b. The group sizes are unequal. The harmonic mean of the group sizes is used. Type I error levels are not guaranteed.

Tabayyun Aspects and Indicators in Preventing Hoaxes on Social Media

Based on the results of survey data analysis on the views of research subjects $(\mathrm{N}$ Total $=514$ ) on the understanding of tabayyun. I found several important terms that exist in tabayyun regarding reporting on social media. As contained in the following chart:

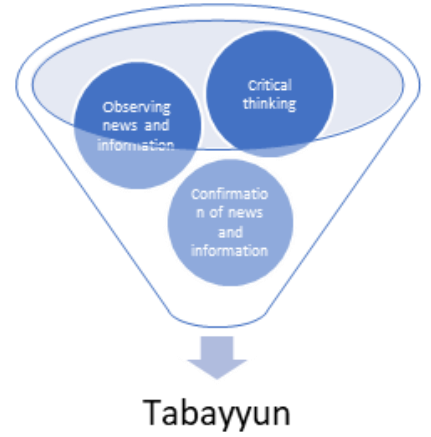

Based on the chart above, I formulated the definition of tabayyun as an effort to find the truth by thinking critically, observing and confirming the news and information obtained. This theme is one of the main themes to uncover the main questions in this research. How to find out the form of tabayyun to overcome hoaxes on social media against the views of research subjects $(\mathrm{N}$ Total $=514)$. In advance, it has been known that the research findings on the important terms in tabayyun towards news on social media consist of: 1) Critical thinking; 2) Observing; 3) Confirm the news and information obtained on social media. These three terms serve as the initial basis for formulating important aspects and indicators of the tabayyun form to overcome hoaxes on social media.
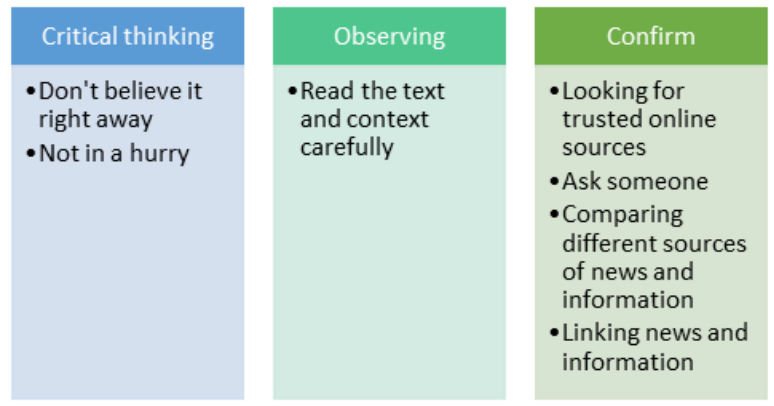

From the chart above, the tabayyun aspects can be explained: 1) Critical thinking aspect: In the form of behavior that does not immediately believe and is not in a hurry in responding to news and information on social media; 2) Aspects of observing news and information on social media: In the form of behavior by reading the text and context widely on the news and information 
obtained; 3) Aspects of confirmation of news and information on social media: In the form of truth-seeking behavior by looking for trusted sources online or asking someone and comparing and connecting some of the news and information.

\section{DISCUSSION}

Hoaxes on social media are a threat to every human being. Highlights the abuse of social media to spread rumors, which, from a technology standpoint, are of almost no help at all in verifying the authenticity of shared messages (Syarifudin, 2019). Content/information that contains praise, flattery, and or positive things about a person or group is not necessarily true, therefore it must also be done tabayyun (Fatwa Majelis Ulama Indonesia Tentang Hukum Dan Pedoman Bermuamalah Melalui Media Sosial, 2017).

In this finding, there are forms of hoaxes, including fake news, false information and not according to facts. Sander van der Liden (2013) said most people assume the weak information obtained from the news. Believing in conspiracy theories cannot be used as a major factor in causing social change. The problem is the need for criticism of the understanding of democracy as an agent of national surveillance against the proliferation of news in various electronic media. Conspiracy theories can finally change people's understanding and attitudes that are inspired by various political interests. The existence of a correct understanding of this situation (hoax reporting) will be an important tool to combat the existence of this news (hoax).

The three forms of hoax are related to each other. Fake news, false information and untruthful facts can all be one at a time. Therefore, hoaxes on social media are part of a combination of the types of lies that exist. Here I show an illustration of the connection between the three forms of hoax on social media in this study:

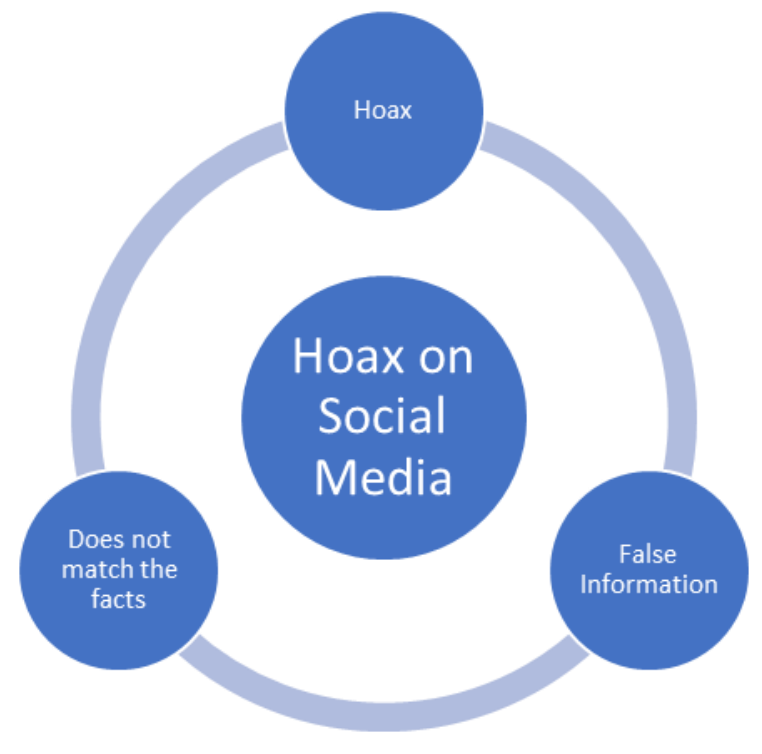

Hax spread after circulating, spread via app gives a personal touch to the message as it is communicated from one known person to another (kehinde, 2016). In the sense that the three forms of hoax above are different on social media. In the findings of this study, there are three types of social media platforms where hoaxes are circulated in the order consisting of Facebook, Instagram and WhatsApp. Here I show an illustration of the spread of hoaxes on social media in the findings of this study:

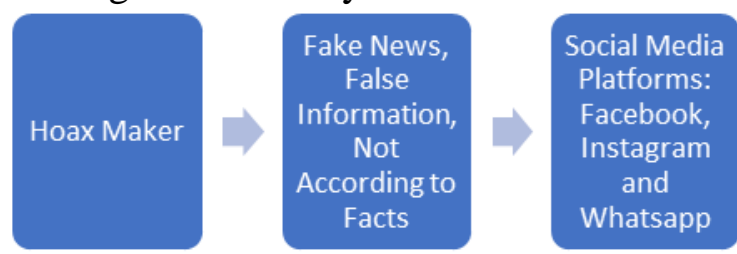

In this regard, the strategy of spreading hoaxes by activists is closely related to the politicization of issues as a communicative tactic to influence the formation of public opinion or change attitudes. Interest groups, individual activists, and other actors spread hoaxes and politicize issues (Bolsen \& Druckman, 2015; Veil et al., 2015). Issues related to political ideology and hoaxes can quickly spread throughout the public network. An individual acts not only as a receiver of heuristic cues but also as a disseminator through simple behaviors such as clicking, liking, sharing, or commenting (Chua, 2012). 
Therefore, in the perspective of Islam, Allah SWT has provided a method to overcome the news that is not yet known to be true. As contained in the QS. al-Hujurat : [49]: 6 .

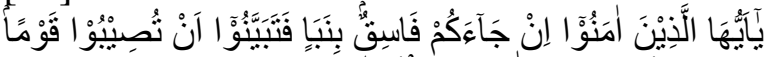

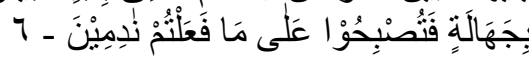

Meaning: "O you who believe! If someone who is wicked comes to you with news, then examine the truth, so that you do not harm a people because of ignorance (recklessness), which in the end you will regret what you did.

The findings of this study found the form of the tabayyun aspect by thinking critically, observing and confirming the news and information obtained.

Implementation of tabayyun by: 1) Thinking critically: In the form of behavior that does not immediately believe and is not in a hurry in responding to news and information on social media; 2) Observing the news and information on social media: In the form of behavior by reading the text and context widely on the news and information obtained; 3) Confirming news and information on social media: In the form of truth-seeking behavior by looking for trusted sources online or asking someone and comparing and connecting some of the existing news and information.

The implementation of tabayyun on students in this study $\mathrm{N}$ Total $=514$ shows the results that have not implemented tabayyun completely, there is still a tendency to ignore tabayyun in responding to news on social media. In the low category, there are still $\mathrm{N}=145$ (28\%) who tend not to use tabayyun. While the average is in the medium range $\mathrm{N}=255$ (49\%) which means that the application of tabayyun is still not optimal in responding to news and information from social media. The rest have done tabayyun $\mathrm{N}=114$ (23\%).

\section{CONCLUSIONS}

This study concludes several findings including: there are three types of hoaxes on social media including: 1) Fake news; 2) False information; 3) Does not match the facts. So the definition of hoax on social media is false reporting or false information that does not match the facts on social media. Aspects of the hoax field in social media include: 1) The political field; 2) Health Sector; 3) Social Sector; 4) Religion sector; 5) Education sector; 6) Economic sector; 7) Cultural field.

Second, the implementation of tabayyun in students has not fully implemented tabayyun, there is still a tendency to ignore tabayyun in responding to news on social media. This is because the understanding of the tabayyun process itself is not yet known.

Third, the form of the application of tabayyun is to seek the truth of critical thinking, observe and confirm the news and information obtained. So the behavioral aspects and indicators of tabayyun are: 1) Critical thinking aspect: In the form of behavior that does not immediately believe and is not in a hurry in responding to news and information on social media; 2) Aspects of observing news and information on social media: In the form of behavior by reading the text and context widely on the news and information obtained; 3) Aspects of confirmation of news and information on social media: In the form of truth-seeking behavior by looking for trusted sources online or asking someone and comparing and connecting some of the news and information.

\section{REFERENCES}

Amra, A. (2016). Pembelajaran Dengan Menggunakan Multimedia Digital. Ta'dib, 15(1). https://doi.org/10.31958/JT.V15I1.218

Atlas.ti. (2021). ATLAS.ti_ManualWin.v9.

Bolsen, T., \& Druckman, J. N. (2015). Counteracting the Politicization of Science. Journal of Communication, 65(5), 745-769. https://doi.org/10.1111/JCOM.12171

Cambridge Assessment International Education. (2018). Global Education Census Report 2018.

Chua, B. H. (2012). Methodological and conceptual issues in cyber activism 
research: Inter-Asia ... - Asia Research Institute - Google Buku. Asia Research Institute.

https://books.google.co.id/books/about/ Methodological_and_conceptual_issues _in.html?id=UeyQzQEACAAJ\&redir_e $\mathrm{sc}=\mathrm{y}$

Creswell, J. W. (2012). Educational research: Planning, conducting, and evaluating quantitative and qualitative research. In Educational Research (Vol. 4). https://doi.org/10.1017/CBO978110741 5324.004

Creswell, J. W. (2014). Research design: qualitative, quantitative, and mixed methods approaches (4th Edition). Sage Publication.

Fathoni, A. B., Verina, A., Rahmah, B., Paiqotul, N., \& Ramdani, Z. (2019). Defining Tabayyun as a Psychological Attribute: Study of Thematical Exploration Introduction Section. International Summit on Science Technology and Humanity (ISETH2019) Advancing Scientific Thought for Future Sustainable Development.

kehinde, mefolere. (2016). WhatsApp and Information Sharing: Prospect and Challenges. International Journal of Social Science and Humanities Research, 4(1), 615-625. https://www.academia.edu/41052195/W hatsApp_and_Information_Sharing_Pro spect_and_Challenges

Fatwa Majelis Ulama Indonesia Tentang Hukum Dan Pedoman Bermuamalah Melalui Media Sosial, Pub. L. No. 24 Tahun 2017, Majelis Ulama Indonesia (2017).

Prasetijo, A. B., Isnanto, R. R., Eridani, D., Soetrisno, Y. A. A., Arfan, M., \& Sofwan, A. (2017). Hoax detection system on Indonesian news sites based on text classification using SVM and SGD. Proceedings - 2017 4th International Conference on Information Technology, Computer, and Electrical Engineering, ICITACEE 2017, 2018-January, 45-49.
https://doi.org/10.1109/ICITACEE.201 7.8257673

Rojko, A. (2017). Industry 4.0 concept: Background and overview. International Journal of Interactive Mobile Technologies, 11(5), 77-90. https://doi.org/10.3991/ijim.v11i5.7072

Seidman, I. (2006). Interviewing as Qualitative Research A Guide for Researchers in Education and the Social Sciences Third Edition. Teachers College Press.

Setiyanto, D. A. (2019). Hoax: Teks dan Konteks dalam Al-Quran. Indonesian Journal of Religion and Society, 1(1), $1-11$.

https://journal.lasigo.org/index.php/IJR S/article/view/5

Singer, J. B. (2008). Five Ws and an H: Digital Challenges in Newspaper Newsrooms and Boardrooms. International Journal on Media Management, 10(3), 122-129. https://doi.org/10.1080/1424127080226 2468

Sugiono, S. (2020). Industri Konten Digital Dalam Perspektif Society 5.0 (Digital Content Industry in Society 5.0 Perspective). JURNAL IPTEKKOM (Jurnal Ilmu Pengetahuan \& Teknologi Informasi), 22(2), 175-191. https://doi.org/10.33164/IPTEKKOM.2 2.2.2020.175-191

Syarifudin, F. (2019). Urgensi tabayyun dan kualitas informasi dalam membangun komunikasi. Al-Kuttab: Jurnal Kajian Perpustakaan, Informasi Dan Kearsipan, 1(2), 29-39. https://doi.org/10.24952/KTB.V1I2.199 4

van der Linden, S. (2013). What a Hoax. Nature Publishing Group, 24. https://doi.org/10.1038/scientificameric anmind0913-40

Veil, S. R., Reno, J., Freihaut, R., \& Oldham, J. (2015). Online activists vs. Kraft foods: A case of social media hijacking. Public Relations Review, 41(1), 103108.

https://doi.org/10.1016/J.PUBREV.201 
4.11.017

World Health Organization. (2006).

Orientation Programme on Adolescent

Health for Health-care Providers Hand
Out New

Modules.

https://www.who.int/maternal_child_ad olescent/documents/9241591269/en/ 